\title{
AS MULHERES NA OBRA DE DIAS GOMES: UMA VERSÃO DA INFIDELIDADE FEMININA
}

Irene Bonan

Centro Federal de Educação Tecnológica de Alagoas

Sendo caracterizado por escrever textos de engajamento político, o que mais nos chama a atenção nas peças de Dias Gomes, são as personagens femininas.

A observação nos detém para a infidelidade conjugal. É difícil se deparar com os textos do autor, onde não haja traição por parte da mulher.

Dentro dessa ótica surgiu a perspectiva de análise do texto Amor em Campo Minado.

O título original da peça em sua primeira versão foi Vamos soltar os demônios. Apesar de ter sido escrita após o golpe de 64, em pleno governo Médici, onde se vivia a era do "Milagre Brasileiro", o país ainda se achava alienado da verdadeira realidade que se passava nos porões da ditadura.

Entretanto, na leitura do texto a resposta aos questionamentos políticos fica por parte do leitor. Na realidade a proposta é apenas uma reflexão através do relacionamento homem-mulher enfocando política e sexo como pólos que se interpenetram, usando o psicológico.

No universo ficcional de Amor em Campo Minado o autor concebe as aventuras amorosas envolvendo os mais diversos sentimentos.

As intrigas da vida em comum de um homem e uma mulher, onde já não cabe tanta paixão, acaba sendo o fio condutor que remete suas personagens para a traição onde o ponto chave das relações de Nara e Sérgio, é a consciência que ela tem de sua própria inferioridade intelectual. Na verdade ela detesta o intelectualismo do marido. Isso a faz se sentir inferior, gerando por consequência uma serie de conflitos. 
O personagem vivido por Sérgio, é retratado na figura de um jornalista intelectual, ativista, liberal, tímido, sujeito a profundas depressões.

Seu espírito é um verdadeiro caos de perguntas sem respostas, embora exteriormente, ele aparente ser exatamente o inverso.

Apesar de seu intelecto superior, sente-se frágil na sua masculinidade, e busca em suas aventuras mulheres que o admirem, que o achem superior no seu papel de macho.

Procura desvendar o autoritarismo e reacionarismo, e acaba se revelando contraditório em relação a sua mulher, personagem vivido por Nara.

Nara é uma garota que tinha acabado de descobrir Simone de Beavouir, começava a assimilar desordenadamente uma porção de idéias sobre sexo, existencialismo etc. Suas experiências sexuais começaram aos dezesseis anos com vários homens. Conhecera Sérgio que acabava de chegar de Paris, onde fora fazer um curso na Sorbonne.

Casada há dezesseis anos, quando estava no $6^{\circ}$ mês de gravidez, sabia o que ele pensava sobre a pratica do sexo antes do casamento. Achava que o perfeito conhecimento sexual entre os cônjujes antes dessa união, era necessário social e moralmente.

Como escritor havia publicado seu primeiro romance com muito sucesso e sua superioridade intelectual era tão grande em relação a Nara , que ela havia se curvado logo as suas idéias. Quando se conheceram, o único sentimento que despertara em Sérgio foi sexo mais nada.

\section{Segundo GiKOVATE (1996, p.18)}

O sexo corresponde a excitação e não a paz e harmonia; além do mais, a sensação de amor só pode se dar ao lado de outra pessoa, ao passo que o sexo pode muito bem exercer de modo solitário. Mesmo quando a excitação sexual é desencadeada em função de uma pessoa, ela pode facilmente ser transferida para outra, o que não ocorre com o amor. Nesse sentimento, é fixo o nosso interesse por uma determinada criatura; por outro lado, podemos sentir 
desejo sexual por várias pessoas ao mesmo tempo. Sexo e amor não só são parte do mesmo impulso como, não raro, estão em antagonismo.

Nesse processo inicia-se uma caminhada a dois repleta de problemas, onde o sexo era prioridade para Sérgio e o amor para Nara. Não havia equilíbrio que conseguisse sustentar esse relacionamento. $\mathrm{Na}$ verdade era a junção de duas pessoas completamente opostas.

Nara se entregou totalmente. Geralmente a mulher "ama demais", ela costuma, justamente por causa desta peculiaridade, envolver-se total e imediatamente, entregar-se sexualmente de uma forma muito intensa, o que de inicio costuma agradar muito aos homens. Porém, logo depois se torna extremamente exigente de companhia e de atenção, pois passa a ter todas as características das pessoas apaixonadas, onde a dependência é máxima.

Segundo HENDRIX, (1995, p.23) o casamento é visto da seguinte forma:

Hoje somos, em nossa sociedade, encorajados a encarar o casamento como uma caixa. Você escolhe o parceiro e, depois entra dentro dela. Compra os eletrodomésticos de última geração, móveis lindos, decora com tapetes, plantas, quadros, transforma a caixa num lugar aconchegante. O importante desse acordo com essa visão é buscar uma parceira não para andar juntos pela estrada da vida, mas sim para dividir o exíguo espaço de uma caixa. E essa busca é uma espécie de loteria, onde você pode ou não tirar a sorte grande. Quem acha que não tirou, escolhe trocar de caixa.

Como na vida real, Nara tenta tampar essa caixa com bastante força, e suportar a frustração e o desapontamento de seu casamento. Esforça-se para acompanhar o nível intelectual do marido, tentando superar a inferioridade que sentia em relação a ele, assimilando um pouco de sua inteligência e de cultura pelo convívio durante os anos que viveram juntos.

Diante dessa fragilidade foi fácil para Sérgio incurtir em Nara o desejo de ser aquilo que ele entendia que uma mulher deve ser para um homem. Consegue amoldá-la dentro dos padrões de uma esposa 
que ele acha perfeita. Passa então a ser um relacionamento egoísta onde ele mais recebia do que dava.

O casamento deles era liberal. Havia um trato entre os dois. Através desse acordo entre eles a traição era aceita, desde que houvesse conhecimento de ambas as partes. Na realidade para Sérgio, traição também era ocultar a verdade dos fatos.

Nesse sentido os diálogos da peça são bem estruturados e revelam intencionalidade que nos permitem fazer esse comentário.

Nara - Bem, você nunca será um marido enganado. Eu direi antes, ou logo depois, segundo o nosso trato. Como você já fez aliás, por duas ou três vezes. Está lembrado?

A recordação irrita Sérgio.

Sérgio - Isso foi há muito tempo

Nara - Você trepou com ela no sofá da sala, ou foi no tapete

Sérgio - Que importa agora se foi no sofá oll no tapete?

Nara - Claro, esse é um detalhe sem a mínima importância. Antes você foi ao quarto e me disse, lealmente, que ia trepar com ela. Explicou que era um impulso irresistivel, mais elevado, que essa união carnal, era algo muito belo, e que eu não deveria sentir-me diminuída com isso. Pelo contrário, eu só me engrandeceria a seus olhos se recebesse aquilo com superioridade e até com satisfação, pois entre as pernas da professora você ia buscar alguma coisa além do sexo. Alguma coisa indefinivel e rara, que faria com que você saísse de lá para mim enriquecido em sua humanidade.

Essa atitude demonstra que Sérgio tinha argumentos suficientes para se justificar. Ele não traía por estar insatisfeito sexualmente com ela. Procurava nas outras mulheres a intelectualidade que Nara não tinha. Na realidade ele estava voltado para si no seu ego-macho tentando através da sexualidade compensar a sua baixa auto-estima. Apesar do seu intelecto superior se sentia 
frágil na sua masculinidade e buscava com suas aventuras, mulheres que o admirassem, que o achassem superior no seu papel de macho.

A necessidade de se sentir superior não deixava perceber que Nara apesar de tão submissa tinha sentimentos.

Como explica COREY, (1995, p.32)

Seja qual for a tendência de cada um, é certo que existe uma grande diferença como os homens e as mulheres vêem a relação extraconjungal. Enquanto a maior parte das mulheres tende a considerar o sexo como um aspecto de amor e da intimidade emocional os homens não o vêem da mesma forma. Muitos consideram-no simplesmente uma diversão. Por isso não sentem tão culpados em relação ao adultério quanto às mulheres.

Eles não acham que seu comportamento sexual não emocional seja uma ameaça ao casamento. A grande maioria dos homens é infiel principalmente por estar em busca de diversão.

Essa anulação e o exagero de participação da vida de Sérgio, levou Nara a fazer muitas concessões e a consequência inevitável foi o acumulo de frustrações que tornara o seu casamento sufocante fazendo com que ela se sentisse humilhada e consequentemente perdendo o encantamento.

Segundo MATARAZZO (1992, p.18),

Por mais intensa e prolongada que seja a fase de uma relação, o desencantamento, no entanto, é inevitável. A gente nunca sabe quanto dura a lua-de-mel. Ela pode durar um dia, um mês, um ano, sete anos. Mas a fase do desencantamento sempre acontece. A desilusão é uma carta do trabalho da vida e não dá pra fazer parte do jogo sem que ela, mais cedo ou mais tarde caia em nossas mãos.

Apesar de certa, ela sempre traz a sensação de que fomos traídos. A expectativa de que tinhamos, encontrado o príncipe encantado, alguém que poderia preencher totalmente nossa existência, se desfaz. Você 
maldiz a sorte, não sabe o que fazer, tem vontade de sumir. Na verdade, esse é o momento de confrontação com as expectativas reais do casamento. É quando começamos a ver diferenças entre imagens que construímos do outro e os seus lados sombrios e cotidianos.

$\mathrm{Na}$ busca de uma estabilidade e segurança afetiva, Nara ainda pagava um preço alto para evitar tensões que decorriam de uma vida autônoma. Assim o desejo de conviver com a intimidade se confundia com a ânsia de manter a estabilidade, levando a suportar o insuportável. Tentando justificar sacrifícios ou frustrações, criou um mundo fantástico onde defesas como a negação e a racionalização foram adicionados para que continuasse a viver uma realização idealizada, distante do que ocorria na vida real.

Foi nesse mundo cheio de fantasias que Nara se deparou com a oportunidade de dizer a Sérgio tudo o que sentia. No ambiente propicio em que este se encontrava, um apartamento especificamente decorado para encontros amorosos, ela passa para um mundo irreal e vive momentos que necessitava para quem sabe talvez, estimular o seu casamento.

As cenas e diálogos que focalizam esta situação estão registrados no quadro IV e III ato da peça. Nesse quadro as ações dos personagens, que começam a evoluir de uma postura individualista, de ofensas e inquietudes, passa para o sentimento de cumplicidade, onde Nara e Sérgio se entregam para viver um instante único.

Excitado, ele a agarra e beija violentamente! Ela corresponde ao arrobo sexual. Os dois caem abraçados sobre o leito.

Sérgio - tenho vontade de acabar com você.

Novamente se beijam e iniciam os preparativos para o ato sexual.

Nara - Vista a batina.

Sérgio - Para que?

Nara - Vista.

Sérgio - Você desejou ser possuída por um padre alguma vez? 
Nara - E você, nunca pensou em ser padre, só para ouvir confissões escabrosas e passa na cara todas as mulheres da freguesia?

Sérgio - Já sim, quando eu era garoto...

Nara - (assume um ar púdico) Padre, eu pequei... e não sei se há perdão para mim. Oh! eu não devia ter permitido.

Sérgio - O padre e a paroquiana ardem de amor um pelo outro! Vêm se encontrar aqui, neste templo de luxúria. (atira-lhe a blusa) tome vista e saia.

Nara-É preciso?

Sérgio - É para que possamos nos compenetrar bem dos nossos papéis.

Essa fantasia sexual refletia no desajuste psicoafetivo de Nara e Sérgio. Era um problema que precisava ser conhecido para ser superado sem enganos, mas com otimismo e realidade. Entretanto o momento foi propício, para realizar de algum artifício como estimulo para o seu desgastado relacionamento sexual.

A personagem de Nara, apesar de ser frágil e submissa, apresenta nesse momento da peça uma ação forte de grande peso. Ela tinha ido ao encontro de Sérgio com uma decisão que poderia mudar o rumo de suas vidas (registrada na p. 376).

Sérgio - E que decisão foi essa que você tomou?

Nara - A de deixa-lo. Vim aqui só para the comunicar.

Sérgio - Muito obrigado. É uma gentileza de sua parte. Nara, você não acha que este nāo, é o momento indicado para brincadeiras de mau gosto?

Nara - Não estou brincando. Sérgio. Eu vou deixalo, isto está decidido. Talvez não o faça neste momento. Mas vou deixa-lo amanhã ou depois.

(Ainda se recusa a acreditar). Você bebeu demais.

Nara - Bebi, sim. Bebi principalmente para ter coragem de the dizer de qualquer maneira, que nossa aventura de dezesseis anos termina aqui. Sei que vou magoar você. Principalmente a sua vaidade. Mas não pode ser de outro modo. 
Sérgio - Nem que você repita mil vezes eu não vou acreditar.

Nara - O que é preciso que eu faça para que você acredite? Que pegue a minha bolsa e vá embora?

(Agora ele se convence e isso o deixa atordoado) $e$ você... para onde vai?

Nara - Vou decidir agora. Donato está me esperando para isso.

Com seu temperamento egocêntrico e vaidoso Sérgio não suporta saber que foi traído. Fica procurando uma justificativa para aquela infidelidade. Torna-se agressivo. Não suporta saber que Nara tenha dormido com outro homem por prazer. E isso já acontecera outras vezes, como ela própria confessara.

Apesar de afirmar que seu casamento era liberal, Sérgio fora ferido em sua masculinidade. Essa confissão justamente no momento crítico que estava passando, prestes a ser preso deixou-o arrasado. Seu projeto amoroso havia fracassado, e por alguns momentos ele perdera seu referencial na vida.

A indiferença de Sérgio e a insatisfação do seu casamento, levou Nara em busca de uma compensação. Uma necessidade não preenchida que se transformou em fome latente que foi saciada ou "enganada" com um relacionamento fora do casamento. Acaba descobrindo que apesar de não se comparar intelectualmente com seu parceiro, é capaz de dar e ter prazer e descobre que o amor pode ser diferente em sexo. Que ser liberal não é permitir que o outro admite e sim ter a oportunidade de escolher entre ser e ter.

$\mathrm{Na}$ realidade Nara ao deixar Sérgio, para ir ao encontro de Donato, experimenta a sensação de liberdade, daí atingindo o ápice de satisfação. Entretanto, ao dirigir-se ao elevador, chega a conclusão que de uma coisa ela não se libertou, o amor que sentia por Sérgio. Dessa forma ela volta para morrer com ele, demonstrando que amar também pode ser uma opção de vida ou de morte. 
AS MULHERES NA OBRA DE DIAS GOMES:

UMA VERSĀO DA INFIDELIDADE FEMININA

\section{Referências Bibilográficas}

COREY, Michael. Adultério- por que os homens traem. [s.l.]Editora Mercuryo, 1992.

GIKOVATE, Flávio. Uma nova visão do amor. São Paulo: MG Editores Associados Ltda, 1996.

HENDRIX. Haville. Getting the love want. Harpes \& Row Publishers, 1988.

MATARAZZO, Maria Helena. Amar é preciso: os caminhos para uma vida a dois. São Paulo: Editora Gente, 1992. 